\title{
Students Choice of a University: Case of the National University of Lesotho (NUL)
}

\author{
Dr. Regina M. Thetsane \\ B.Ed. MBA. PhD Business Admin \\ Faculty of Social Sciences \\ National University of Lesotho. 180. Lesotho. \\ Dr. Motšelisi C. Mokhethi \\ B.Ed. MBA. PhD Entrepreneurship \\ Faculty of Social Sciences \\ National University of Lesotho. 180. Lesotho. \\ Mr. Bukenya M. Patrick \\ B. Com (Hons) ACMA, GCMA. \\ Faculty of Social Science \\ National University of Lesotho. 180. Lesotho
}

\begin{abstract}
The study aimed at identifying factors that are perceived to be significant in choosing an institution is pivotal to inform the marketing approach for universities. The National University of Lesotho (NUL) was used as a study setting where a sample consisted of 400 for the population size of 1758 was settled for and a stratified probability sampling technique used to select respondents. A total of 270 questionnaires were returned representing a response rate of 60\%. Reference group was the top important factor that influences students' choice of university, followed by institutional while the least significant factor was media. The correlation results revealed strong association between and amongst the three factors identified. Universities should be encouraged to match their offerings with the identified factors in order to increase enrolment. They should pay attention to these factors and reflect on their recruitment and marketing strategies to attract potential and retain existing students.
\end{abstract}

Keywords: Universities, Student choice, Higher Education, First year Students.

\section{Introduction}

In recent years, Lesotho higher learning education landscape has gone through some changes. There has been some growth in the number of the Lesotho higher learning institutions, in particular the universities. This has been prompted by the entrance of two private universities in the higher learning institution sector in Lesotho in 2008 and 2015 respectively. Since 1975 (NUL calendar, 1987-1988)to 2008, NUL has been enjoying the monopoly of being the only university in the country. The entrance of the two private universities in the higher learning sector in Lesotho introduced choice for learners while triggering competition between and amongst universities and learners. Universities compete for high performing students while learners fight for a place in a better performing university.

Campell (2000) argues that due to competitive environment amongst universities increased options for students to choose from therefore, higher learning institutions need to behave strategically to attract students and raising their education quality, which have an impact on students' decision of choice of a university. Some of the new developments in the Lesotho higher learning sector include accreditation of higher learning institutions and declining funding of higher education by the Lesotho government. All these developments have impelled the recognition that a thorough understanding of the factors influencing learners in choosing a university, especially the new entrants into the undergraduates programmes of the university is essential to guide marketing strategies meant to recruit students.

Choosing a suitable university to apply to is an important decision for any students. It does not only affect students' orientation of future career but also influences their motivation to study, commitment and interaction with the university. In fact, not being rational in choosing a university, students may have difficulties in maintaining learning motivation, achieving high academic results and getting a desirable job. Discovering factors which drive students' choice of universities is, therefore, critical to inform the marketing strategies for any higher institution. 
Furthermore, understanding factors impacting students' choice of university is the basis for recruiting strategies and the implementation of relevant programs, which decides the survival and development of each university in the competitive environment of higher education provision. In fact, Zhi-Hong, (2014) observed that the atmosphere of university education has increasingly become competitive as a result universities have tocompete with each other to attract students in the recruitment markets. As competition in the higher education increases, universities are now faced with the problem of competing for students to improve enrolment. Attempt to increase enrolment in this case calls for the application of the marketing concept. The marketing concept states that, in order to be successful, an institution must identify the needs and wants of specific target markets and deliver the desired satisfactions better than competitors (Schiffman \& Kanuk 2010). By application, universities must identify the needs and wants of students in respect to the motivation factors that influence students' choice of a university in Lesotho. Therefore, it is very important for universities in Lesotho to pay attention to the competitive environment prevailing in the country, particularly, in this era where universities are confronted with the decrease in the number of students (Matsolo, Ningpuany \& Susuman, 2016). Research shows that there are many factors that influence student's choice of a university. As Kusumawati, Yanamandram, and Perera (2010a) state that each factor has a different level of importance for every country and each student. The current paper therefore, focuses on exploring significant factors which affects students' choice of university in Lesotho.

The paper provides valuable information for higher learning institutions to be better aware of their students' needs and wants as customers so that appropriate marketing strategies can be designed to meet the needs of the students in order to make them satisfied. It will also help to equip the educational policy makers of universities in formulating; implementing and modifying educational policy for the expansion of the higher education system in Lesotho. Specifically, this study answers the following questions: What factors influence choice of university among NUL students? Which factors are perceived to be significant in their choice of NUL?

\section{Literature review}

A number of research has been done on factors influencing student's choice of university. These studies were conducted based on economic, social and collective perspectives (Kim \& Gasman, 2011). All these studies found different factors that influence university choice in diverse context and locations. However, depending on the context and circumstances, many researchers had found similar factors but the degree of importance varies (Maniu, I. \& Maniu. G. 2015). Research on university choice factors has shown that there are common elements across nations and some of such factors are: reputation of the institution, institutional location, availability of financial Aid /sponsorship, marketing factors, personal factors, reference group and academic programme. However, they will differ depending on different environment, context and countries.

An institutional reputation is a core intangible asset of an institution and it creates barriers to competitive threats (Ravasi \& Fombrun, 2004). A strong institutional reputation suggests that the products and services offered by the institution are of higher quality (Carmeli \& Freund, 2005) and that the institution is responsible and will treat its customers well. As a result, institutional image has a powerful influence on making the decision to attend a university. Keling (2006) stated that the most influential factor that influences students in selecting a university is the reputation of the university. However, many studies have shown that proximity to home is one of the most important effects on choice process (Alves \& Raposo, 2007; Dawes \& Brown, 2005), as some students may be looking for a university close to their hometown or place of work for convenience and accessibility (Absher \& Crawford, 1966). On the other, Hossler and Gallagher (1987) concluded that the proximity to a university affect attendance of students positively. Students who stay close to a campus are more likely to choose university though they may not attend the campus located near home (Ming, 2010). In a study of Ozdemir and Hacifazlioglu (2008) the majority of the participants stated that the location of a university affected their decision on the choice of university.

Financial assistance offered by universities is one of the most important attributes expected from a particular higher education institution of choice (Yusof et al, 2008). It reduces the costs which are supposed to be borne by students. Thus, students who receive financial aid awards are more likely to enter universities, more so, in countries whereby the rate of unemployment is high. Tamtekin (2015) observed that for some students the choice of an institution is constrained by financial aspects and financial aid-scholarship can be necessary to expand their choice. However, Hoyt and Brown (2003) argued that financial aid, scholarship, loans or grants are very important factors in making a choice of university. Therefore, most of the universities attract potentially good students by offering financial benefits. This affects the students' choices as they may then put more consideration into institutions with the most generous offer.

Briggs (2006) argues that satisfaction of the needs of the students is of paramount importance for effective learning of students. Therefore, marketing is necessary in education as it helps universities to provide the qualifications that satisfy the needs of the students. 
Marketing factors that include advertising, campus visits, career fairs and cost of university education have an influence on the decisions of students to choose a university (Rudhumbu, 2017). Ming (2010) argued that advertising influences student choice of a university, especially the social media, as research has shown that most of the youth spend most of their time on social media. Institutions can use the social media to build their institutional image and to create brand awareness amongst the youth, as they are their main target market. Briggs (2006) also emphasized the importance of campus visits, as one of the influencing choice factor. He indicated that the best way to find out about universities and the courses they offer is to physically visit them. Other sources such as publications, television and media advertising, leaflets, newspaper and magazines are regarded as valuable, particularly for students in the rural areas who do not have access to internet facilities (Maniu, I. \& Maniu. G. 2015). Pampaloni (2010) emphasized the importance of internet and particularly university website, student's social networks as very critical in influencing student's choice of university.

Coccari and Javalgi (1995), Donnellan (2002), Holdsworth and Nind (2006), Shank, Quital and Taylor (2005) validated the importance of marketing factors on university choice process. Campus visits and open days provide the opportunity to talk to staff and students although, with thousands of students wandering round campuses, it may be difficult to meet and talk to the right people (Hoyt \&Brown, 2003). Shank et al, (2005) maintained that an effective marketing helps students create real expectations about what the universities offer and what commitment and involvement is needed without having unreal expectations and promises about offers which cannot be kept. It is important for institutions to understand what attracts the prospect students in a university compared to another and ensure that those expectations are met. However, Price et al, (2003) argue that the most influencing factor in choosing an institution is non-marketing, such as, parents and friends. Conversely, Bergerson (2009) cited cost of university as one of the most influencing institutional attribute in choosing a university. Before making any choice, students estimate how much money they will have to spend on a good education. According to Tamtekin (2015) it does not only mean university fees but also includes accommodation, food and transportation costs.

Age, gender, family background, occupation, socio- economic circumstances and lifestyle are considered as personal factors influencing the choice of university. Before choosing a university students go through three decision sets namely: student's awareness set, consideration set and choice set (Dawes \& Brown, 2005). Personal preference is the most critical influential factor in university selection in Turkish students (Yamamoto, 2006). Alternatively, Wargner and Fard (2009) argued that socio-economic circumstances of the family, especially financial resources are one of the most influential factor in choosing a university to attend. Nonetheless, Avery and Hoxby (2004) observed that students who have higher socio-economic background with strong financial resource and whose parents had earned a bachelor degree do not put financial support from the university on top priority. Depending on circumstances and countries personal factors have the most positive influence on student's choice of a university (Raposo \& Alves, 2007).

A reference group refers to a group of people we compare ourselves to for information regarding behavior, attitudes or values (Hoyer \& MacInnis, 2001). Lamb, Hair, McDaniel, 2002) argue that reference groups can either be direct or indirect. The direct reference groups touch people's life directly, for instance, parents, siblings, friends and teachers. As such, they can influence psychological core and the process of making decisions by affecting who we get information from and how we evaluate it. Direct reference groups influence people to behave and make the decision in a certain way. Among those who have influence on student's choice of university parents and siblings are considered the most important ones (Briggs 2006), as they do not act as reference but provide financial commitment and support for their children. As a result, financial support from one's family might result in limitation of one's decisions concerning one's academic future (Pimpa, 2004). In support of Pimpa (2004), Murphy (1981) observed that most students perceive their parents to be the most influencing factor to their choice, especially in terms of financial support.

In contrast, Issac, Malaney and Karra (1992) found the relationship between parent's educational background and student choice in that male student's decision are mostly affected by their father education than their mothers. In some studies, the reference group includes siblings, friends, relatives, teachers and other people that play an important role in student life (Kusumawati, Yanamandran and Perera, 2010b). This was supported by Kim and Gasman (2011), Avinash and Babli (2017) who argued that friends, peers and teachers have a major role in influencing student's choice of university. Moreover, the results of Fletcher's study (2012) are similar with those of Pimpa (2005) who argued that students are influenced by their peers in selecting a university to attend. Commonly, reference groups influence university choice decision of students but they do not have any limitation related to their choice that has a great effect on their life (Tamtekin, 2015). Parents, teachers, peers, siblings' relatives can only make suggestions but do not impose any obligation (Raposo \& Alves, 2007). Availability of required academic programme was cited as the very important attributes for the first year university students to choose a particular higher education institution (Yusof et al, 2008). Keling, Krishnan and Nurtjahja (2007) surveyed institution and found students placed the highest importance on factors regarding program of study, tuition cost, financial aid, and job placement when selecting a college. 
Nurlida et al, (2010) concede that the more the attributes meet the expectations of students based on information gathered, the higher the enrolment at the university. Students evaluate programmes based on: selection of courses, availability of courses and entry requirements; quality and variety of education (Shanka, Quintal and Taylor, 2005); and quality and flexibility of degree/course combinations (Holdsworth \& Nind, 2006).

\section{Methodology}

The research design for this paper is descriptive due to the fact that the study seeks to identify the factors that influence students' choice of the university in Lesotho. The target population was composed of all first year students of NUL in the academic year 2017/2018. Sekaran and Bougie's (2013) table of sample size was used and a sample of 400 for the population size of 1788 was adopted. Stratified probability sampling was used to select students from the seven NUL faculties and within each strata (faculty) simple sampling technique was used to select students from each faculty (Table 1.1).

A self-developed questionnaire was of three sections. Section A was designed to collect demographic data of the students. B concentrated on the values and goals of the students. Part C concentrated on the factors that influence the respondents' choice of university and utilizes 5 point Likert-scale where respondents were required to indicate their response between two extreme points, thus, high importance and not very important. The last part was centered on other significant factors influencing students 'choice of university'. The questionnaire was administered in the first semester of the university after the students had registered in the academic year 2018/19. 270 questionnaires were returned and authenticated representing a response rate of 60\%. The Statistical Package for Social Sciences(SPSS) program was used to analyze the data using factor analysis with principal component extraction and correlation analysis to determine the relationship between the factors that affect the student's university choice.

\section{Findings of the study}

As far as the students' gender is concerned, male students accounted for $39 \%$ of the total sample while female students was $61 \%$. The results are consistent with NUL overall statistics enrolment (2018/19) by gender whereby females' students account for a larger percentage (63\%) than males with (37\%) (NUL Statistics enrolment by gender academic year 2018/19). Again, majority of the respondents in this study constituting $82 \%$ were between the ages $18-23$, while $12 \%$ were above 23 and $6 \%$ were below18 years. The results indicate that the average age of NUL first year student's fall between 18-23 years.

\subsection{Factor analysis}

To identify the factors that influence student's choice of university and to determine construct validity of the instrument an exploratory factor analysis was performed. The factor analysis produced 3 factors (Table 1.2). Factor 1 is named, media influence (made up of 5 variables) factor 2 is institutional related influence (made up of 3 variables) and factor 3 is direct reference group (made up of 4 variables). Two items of the eighteen variables were eliminated because they both loaded in more than one factor. This result shows the importance of the three factors in choosing an institution of study. Cronbach's alpha coefficients, estimating internal consistency of each factor were calculated as $\alpha=0.91$ for media influence, $\alpha=0.89$ for university related influence, $\alpha=0.70$ for direct reference group (Table 1.3). An alpha coefficient of 0.7 is considered and indicates high reliability of the measuring scale (Pietersen \& Maree 2016; Cohen, Manion \& Morrison, 2007). All these coefficients are in the range that suggests high reliability of the measuring scale, therefore the instrument used is reliable.

\subsection{Descriptive results}

The findings of descriptive statistics of the factors affecting students _ ' university choice are given in Table $\quad$ 1.4. Mean $(\overline{\mathrm{x}})$ and standard deviation were used to describe the importance of factors that affect students' university choice. As it can be seen from Table 1.3, when the descriptive statistics of the factors affecting university students' choice are examined, it is seen that while the most important factors affecting students' choice are "Direct reference groups influence" ( $\overline{\mathrm{x}}=3.62)$ followed by "Institutional related influence" $(\overline{\mathrm{x}}=3,25)$; the least important factor is "Media related influence" $(\bar{x}=2,73)$. The results show that direct reference group (fathers, mothers, teachers and friends) has a major impact in influencing students' choice of university. It affects student's choice of an institution more directly than most other social influences on consumer decision making.

\subsection{T-test results}

The results of the t-test analysis on the comparison of the importance given to the factors influencing the choice of university are given in Table 1.5. As shown in Table1.5, there are significant differences in three variables (MediaInstitutional and Reference) that influence student's choice of university. The influence of reference group $(\overline{\mathrm{x}}=3.62)$ was significantly greater than the influence of institutional $(\bar{x}=3.25), t(157)=0.4205, p<0.01)$. 
Similarly, the influence of reference group $(\overline{\mathrm{x}}=3.62)$ was significantly greater than the influence of media $(\overline{\mathrm{x}}=2,73), \mathrm{t}$ $(155)=10.021, \mathrm{p}<0.01)$. The same result was found where students give more importance to institutional variable $(\overline{\mathrm{x}}=$ $3,25)$, than media variable $(\bar{x}=2.73), t(179)=0.4808, p<0.01)$ in choosing a university of study.

\subsection{Correlation results}

Table 1.6 presents the results of correlation analysis to determine the relationship between the three factors that affect the student's university choice. As can be seen from Table 1.6, the correlation results show a significant positive relationship between the influence of media with the influence of the university related factor $(r=0.576, \mathrm{p}<0.01)$ in choosing university of study. There is also a significant relationship between the influence of direct reference group with university related factors influencing student's choice of university $(r=0.391, \mathrm{p}<0.01)$. The direct reference groups have a positive and significant relationship to media related factors $(r=0.529, \mathrm{p}<0.01)$.

\section{Conclusion of findings}

While the study was limited in scope to NUL first year's students in Lesotho, the results may show factors which extend beyond Lesotho. The findings of this study revealed a number of factors influencing student's choice of university; however, such factors differ in terms of their degree of importance in choosing a university to attend. These factors are group into three main categories, namely: Direct reference group, Institutional and Media related factors.

\subsection{Direct reference group factor}

Direct reference group (fathers, mother's friends, peers, teachers and siblings) was found to bethe most influential factor in choosing an institution in Lesotho. Parents, in particular serve as a major influence in their children's career development and career decision-making and one factor which influences happiness and success is the right university choice (Keller 2004). Bregman and Killen (1999) discovered that students value parental influence and guidance in the area of an institutional choice, as they pay much attention to what parents expect of them, particularly in choosing a university. Therefore, parents' financial concerns and expectations play a part in their direct or indirect influence on their children's university choice by adding their own biases and attitudes into particular occupational fields (Clutter, 2010). Briggs (2006) also contended that high school teachers are universities' utmost allies in assisting students' decision making about the choice of university.

However, Price et al, (2003) argued that parents, friends and teachers are mainly influential in choosing a program and not university. Unlike, Price et al, (2003) this research demonstrates that parents, friends, teachers and siblings have a major significant influence in choosing a university to attend. This can be attributed to the fact that in Lesotho there is a stronger close relationship between parents and children. On the other hand, it might be that probably majority of Lesotho parents are only familiar with NUL, which is the oldest university in Lesotho. Thus, the reason why they don't make an effort to search for other alternatives. The results of this study is also consistent with Maniu, I.and Maniu, G. (2015), Perna (2006) and Al Yousef (2009) who concluded that the recommendations that come from families, peers, friends, teachers and reference groups have a strong influence and considered trustworthy in choosing a university to attend.

\subsection{Institutional factor}

The second factor that was found to be influential was the factor related to institution (university posters, university websites, university internet, university radios, newspapers and local radios). These are methods of getting information about the university. They are related to how an institutions market themselves and provide information for students to make informed decision in choosing a university to attend. The internet, especially the university websites were cited as the most influential factor in selecting an institution to attend (Pampaloni, 2010, Kim \& Gasman, 2011).These results are confirmed by Ariffin et al (2008) and also Keling, Krishnan and Nurtjahja (2007) who found that university websites and newspapers were influential in selecting an institution to attend while a study by Ismail (2009) and Keling (2006) found that institutional image and reputation, had a high explanatory power on how students decide on which university to study at (Pampaloni, 2010). Internet, university websites, social networks and mailed brochures are very important and influential in choosing a university to attend (Fischbach, 2006). However, Maniu, I. and Maniu, G. (2015) emphasized that universities websites should be easy to navigate and include correct and targeted information written for prospective and current students with videos displaying students' experience of the university.

\subsection{Media related factor}

The least significant factor among the three that were studied is the Media related factor (the university visits to high schools, visits by university representatives and carrier fairs organized by Council on Higher Education in Lesotho). Kim and Gasman (2011) emphasized the importance of schools visits by university representatives, visits to campuses, open doors days in choosing an institution to attend. 
Visits to high schools by university representatives were rated as an extremely effective influencer in choosing university to attend (Lay \& Maguire, 1981). The same results were found by Hossler, Schmit and Vesper (1999) who also argued that university visits can be very conducive and beneficial for both students and institutions by not only advertising but also giving some information about their facilities. Other media factors, such as, television, newspapers and magazines, media advertising (not written by the institution) are used by institutions to place advertisements that include information on education, social facilities and contact information (Osoro, Amundson, \& Borgen, 2000; Hoyt, Brown, \& BJL, 2003) and as a result they have great influence on the choice of university to study.

\section{Conclusion}

In conclusion, there is a positive relationship between and amongst the three factors identified as the main influential factors in choosing a university to attend. Therefore, the results and findings of this study may provide institutions, colleges and educational marketers with some insight into the factors to pay attention to when it comes to marketing their institutions. Given the current setting of higher learning sector in Lesotho, institutions are also encouraged to match their offerings with the identified factors that influence student's choice of university in order to increase enrolment. Lastly, universities should pay special attention to these important factors and reflect on their recruitment and marketing strategies to attract potential and retain existing students.

Table 1.1: Number of $1^{\text {st }}$ year students admitted in 2018/19 per faculty.

\begin{tabular}{|c|c|c|}
\hline Faculties & $\begin{array}{l}\text { No of first year students } \\
\text { admitted per faculty - } \\
\text { 2018/2019 }\end{array}$ & Sample size in each faculty \\
\hline Faculty of Agriculture & 146 & 32 \\
\hline Faculty of Education & 187 & 40 \\
\hline Faculty of Health Science & 216 & 47 \\
\hline Faculty of Science and Technology & 212 & 45 \\
\hline Faculty of Humanities & 220 & 47 \\
\hline Faculty of Law & 133 & 29 \\
\hline Faculty of Social Sciences & 744 & 160 \\
\hline TOTALS & 1788 & 400 \\
\hline
\end{tabular}

Table 1.2: Exploratory Factor analysis results

\begin{tabular}{|l|c|c|c|}
\hline \multirow{2}{*}{} & \multicolumn{2}{|c|}{ Factors } \\
\cline { 2 - 4 } & $\begin{array}{c}\text { Media } \\
\text { influence }\end{array}$ & $\begin{array}{c}\text { Direct reference } \\
\text { influence }\end{array}$ \\
\hline Local radios & $\mathbf{. 8 7 2}$ & & \\
\hline Newspapers & $\mathbf{. 8 4 9}$ & & \\
\hline University radios & $\mathbf{. 7 1 4}$ & & \\
\hline University posters & $\mathbf{. 7 0 9}$ & & \\
\hline University websites & $\mathbf{. 7 0 3}$ & & \\
\hline University Representatives & & $\mathbf{. 8 3 0}$ & $\mathbf{. 7 9 4}$ \\
\hline University Visits to my school & & $\mathbf{. 8 0 6}$ & $\mathbf{. 6 6 4}$ \\
\hline Visits to career fair organized by CHE & & $\mathbf{. 6 3 5}$ \\
\hline Influence by mother & & & \\
\hline Influence by Father & & & \\
\hline Influence by teachers & & \\
\hline Influence by Friends & & \\
\hline $\begin{array}{l}\text { Extraction Method: Principal Component Analysis. } \\
\text { Rotation Method: Varimax with Kaiser Normalization. }\end{array}$ & & \\
\hline a. Rotation converged in 6 iterations. & & \\
\hline
\end{tabular}


Table 1.3: Cronbach's alpha reliability coefficient

\begin{tabular}{|l|l|l|}
\hline Variables & Cronbach's Alpha & Number of items \\
\hline Media influence & 0.91 & 5 \\
\hline Institutional related influence & 0.89 & 3 \\
\hline Direct reference groups & 0.70 & 4 \\
\hline
\end{tabular}

Table 1:4 Descriptive statistics on media, institutional and direct reference

\begin{tabular}{|l|l|l|}
\hline Factors & Mean $(\overline{\mathrm{x}})$ & Std. deviation \\
\hline Media related influence & 2.73 & .13 \\
\hline Institutional related influence & 3.25 & .13 \\
\hline Direct reference groups & 3.62 & .84 \\
\hline
\end{tabular}

Table 1.5 Paired Samples Test

\begin{tabular}{|c|c|c|c|c|c|c|c|c|c|}
\hline \multirow{3}{*}{\multicolumn{2}{|c|}{ Variables }} & \multicolumn{5}{|c|}{ Paired Differences } & \multirow[t]{3}{*}{$\mathbf{t}$} & \multirow[t]{3}{*}{ df } & \multirow[t]{3}{*}{ Sig. } \\
\hline & & \multirow{2}{*}{ Mean } & \multirow{2}{*}{ SD } & \multirow{2}{*}{ SE } & \multicolumn{2}{|c|}{$\begin{array}{l}\text { 95\% Confidence } \\
\text { Interval of the } \\
\text { Difference }\end{array}$} & & & \\
\hline & & & & & Lower & Upper & & & \\
\hline Pair 1 & Media - Institutional & -.46 & 1.28 & 0.09 & -.64 & -.27 & -4.80 & 179 & .000 \\
\hline Pair 2 & Media - Reference & -.94 & 1.18 & 0.09 & -1.13 & -.76 & -10.02 & 155 & .000 \\
\hline Pair 3 & Institutional - Reference & -.44 & 1.33 & 0.10 & -.65 & -.23 & -4.20 & 157 & .000 \\
\hline
\end{tabular}

Table 1.6: Inter-correlation of variables results

\begin{tabular}{|c|c|c|c|}
\hline Variables & Media related influence & $\begin{array}{c}\text { Institutional related } \\
\text { influence }\end{array}$ & $\begin{array}{c}\text { Direct reference group } \\
\text { influence }\end{array}$ \\
\hline Media related influence & 1 & & \\
\hline Institutional related influence & $\mathbf{0 . 5 7 6 * *}^{* *}$ & 1 & 1 \\
\hline Direct reference group influence & $\mathbf{0 . 5 2 9 * *}^{0 . * 3}$ & $0.399^{* *}$ & \\
\hline
\end{tabular}

** Correlation is significant at the 0.01 level (2-tailed)

\section{References:}

Absher, K. \& Crawford, C. (1996). Marketing the community college starts with understanding student's perspective. Community College Review, 28.59-68.

Al Yousef, H. (2009). 'They know nothing about university - neither of them went': The effect of parents' level of education on their involvement in their daughters' higher education choices. Compare: A Journal of Comparative and International Education, 39(6), 783-798.

Alves. H. \& Raposo, M. (2007). Conceptual Model of Student Satisfaction in Higher Education. Total Quality Management (17), 9, 1261-1278.

Ariffin, A. A., Ahmad, A. H., Ahmad, M. S. \& Ibrahim, M. A. (2008). Determining decision-making styles and demographic differences in selecting higher education services among Malaysian. International Journal of Business and Society, 9(1), 1-18.

Avery, C. \& Hoxby, C. M. (2004). Do and should financial aid packages affect students' college.

Avinash. T. \& Babli K.I (2017). Factors that Influence Undergraduate Students' Choice of a University: A Case of Botho University in Botswana. International Journal of Learning and Development. 7, (2). Online http://ijld.macrothink.org

Bergerson, A.A. (2009). Special Issue. College choice and access to college: Moving policy research and practice to the $21^{\text {st }}$ century. ASHE Higher Education Report, 35. (4), 1-134.

Bregman, G.\& Killen, M. (1999). Adolescents' and young adults' reasoning about career choice and the role of parental influence. Journal of Research on Adolescence, 9, 253-75. 
Briggs, S. (2006). An Exploratory study of the factors influencing undergraduate student choice: the case of higher education in Scotland. Studies in Higher Education, 31 (6), 705-722.

Campell. H. (2000). What have we learned about generic competitive strategy? A meta-analysis. Strategic Management Journal, 21(2), 127-154.

Carmeli. A. \& Freund, A. (2002). The relationship between work and workplace attributes and perceived external prestige. Corporate Reputation Review, 5(1), 51-68.

Chapman, D. (1981). A model of student college choice. Journal of Higher Education, 52(5), 490-505.

Clutter, C. (2010). The effects of parental influence on their children 's career choices. Kansas state university. Manhattan, Kansas

Coccari R. L. \& Javalgi, R. G. (1995). Analysis of students needs in selecting a college or university in a changing environment, Journal of Marketing for Higher /education, 6(2), 27-40.

Cohen, L., Manion, L. \& Morrison, K. (2007). Research Methods in Education $6^{\text {th }}$ ed. Routledge: USA \& Canada

Dawes, P.L. \& Brown, J. (2005). 'The Composition of Consideration and Choice Sets in Undergraduate University Choice: An Exploratory Study'. Journal of Marketing for Higher Education, 14, (2), 37-59.

Donnellan, J. (2002). The impact of marketer controlled factors on college choice decisions by students at a public university. Accessed through http://scholaworks.umass.edu/dissertations on 18th May, 2019.

Fischbach, R. (2006). Assessing the Impact of University Open House Activities. College Student Journal, 40. (1), $227-$ 34.

Fletcher, J.M. (2012). Similarity in peer college preference: New evidence from Texas. Social Science Research, 41(2), 321-330.

Holdsworth, D. K. \& Nind, D. (2006). Choice Modelling New Zealand high School seniors' preferences for university education. Journal of Marketing for Higher Education, 15(2), 81-102.

Hossler, D. \& Gallagher, K. (1987). Studying Student College Choice: A Three-Phase Model and the Implications for Policymakers. College and University, 62, 207-221.

Hossler, D., Schmit, J. \& Vesper, N. (1999). Going to college: How social, economic, and educational factors influence the decisions students make. Baltimore, Maryland: The John Hopkins University Press.

Hoyer, W.D. \&. MacInnis, D.J. (2001). Consumer Behavior. Houghton Mifflin. Pennsylvania State University

Hoyt, J. E. \& Brown, A.B. (2003). Identifying college choice factors to successfully market your institution. College and University, 78(4), 10.

Hoyt, J. E., Brown, A. B., \& BJL, M. (2003). Identifying college choice factors to successfully market your institution. College and University, 78(4), 3-10.

Issac, P.D., Malaney, G. D. \& Karras, J.E. (1992). Parental education, gender differences and senior's aspiration for advanced study. Research in Higher Education. 33(5), 596 - 606.

Keling, S. B. A. (2006). Institutional factors attracting students to Malaysian institutions of higher learning. International Review of Business Research Papers, 2(1), 46-64.

Keling, S. B. A., Krishnan, A. Nurtjahja, O. (2007). Evaluative criteria for selection of private universities and colleges in Malaysia. Journal of International Management Studies, 2(1), 1-11.

Keller, B. K. (2004). Parental behaviours that influence adolescents career development. National career development association. Retrieved on $16^{\text {th }}$ April, 2019 from http://associationdatabase.com/aws/NCDA/pt/sd/news_article/4911/_PARENT/layout_details/false.

Kim, J.K., \& Gasman, M. (2011). In search of a Good College: Decisions and Determinations behind Asian America Students' college choice. Journal of college Student Development, 52(6), 706-728.

Kusumawati, A., Yanamandram, V. K.\& Perera, N. (2010a). Exploring student choice criteria for selecting an Indonesian public university: A preliminary finding. Accessed through http://ro.uow.edu.au/cgi/viewcontent.cgi?articles. $18^{\text {th }}$ November, 2018.

Kusumawati, A., Yanamandram, V.K. \& Perera, N. (2010b). "University marketing and consumer behavior concerns: the shifting preference of university selection criteria in Indonesia," 2010 Asian studies Association of Austria $18^{\text {th }}$ Biennial conference, 1-16.

Lamb, C.W., Hair,J. F. \& McDaniel C. D. (2002). Marketing. (6 ${ }^{\text {th }}$ ed) Publisher South-Western, Cornell University.

Lay, L. \& Maguire, J. (1981). Modeling the college choice: image and decision. College and University, 56, 113-126.

Maniu, I \& Maniu, G. (2015). Educational Marketing: Factors influencing the selection of a university. SEA - Practical application of Science. Vol 11, 3 (5)

Matsolo. M.J., Ningpuanyeh, W.C.\& Susuman. A.S. (2016). Factors Affecting the Enrolment Rate of Students in Higher Education Institutions in the Gauteng province, South Africa. Journal of Asian and African Studies 117. 
Ming. J.S.K. (2010). Institutional factors influencing student's college choice decision in Malasia: A conceptual Framework. International Journal of Business and Social science. (1). 3.

Murphy, P. (1981). Consumer buying roles in college choice: parents and students perceptions. College and University, 56(2), 140-150.

National University of Lesotho Enrolment statistics by gender academic year 2018/19. Report. Roma. Lesotho.

National University of Lesotho, (1987). National University of Lesotho Calendar 1987 - 1988. Morija Printing Works. Lesotho.

Nurlida, I., Hassan, F., Mohamad S. N.\& Mohd D. N. (2010). Determining Mediating Effect of Information Satisfaction on International Students' College Choice: Empirical Evidence in Malaysia's University. International Journal of Scientific Research in Education, Vol. 3(1), 51-63.

Osoro, B. K., Amundson, N. E.\& Borgen, W. A. (2000). Career decision-making of high school students in Kenya. International Journal for the Advancement of Counselling, 22(4), 289-300.

Ozdemir, N.\& Hacifazlioglu, O. (2008). Influence of family and environment on students' occupational choices and expectations of their prospective universities. Social Behavior and Personality: An international journal, 36, 433-446.

Pampaloni, A.M. (2010). The influence of organizational image on college selection: What students seek in institution of higher education? Journal of Marketing for Higher Education, 20(1), 19-48.

Perna, L. W. (2006). Studying college access and choice: A proposed conceptual model. HIGHER EDUCATION, 9915.

Pietersen, J.\& Maree, K. (2016). Standardization of a questionnaire. In K. Maree (Ed). First steps in research. Pretoria: Van Schaik. 237-247.

Pimpa, N. (2004). The relationship between Thai student' choice of international education and their families. International Education Journal, 5(3), 352-359.

Price, I., Matzdorf, F. Smith, L. \& Agahi, H. (2003). The Impact of facilities on Student choice of university. Journal facilities. 21. (10), 212-222.

Raposo, M. \& Alves, H. (2007). A Model of university choice: an exploratory approach MMPRA Paper 1(5523), 203346.

Ravasi, D. \&Fombrun, C. (2004). Analyzing industry reputation in the Italian banking sector, conference paper, 8th International Conference on Corporate Reputation, Image Identity, and Competitiveness, Fort Lauderdale

Rudhumbu. N. (2017). Factors that influence undergraduate student choice of a university: A case of Botho University in Botswana. International Journal of learning and Development (7), 2

Schiffman, L. \& Kanuk, L.L. (2010). Consumer Behavior, Global $10^{\text {th }}$ Edition. United State of America: Pearson Education, Inc.

Sekaran, U. \& Bougie, R. (2013). Research methods for business: a skill-building approach. ( $6^{\text {th }}$ ed.) United Kingdom: John Wiley \& Sons Ltd.

Shank, T., Quintal, V. \& Taylor R. (2005). Factors influencing International Students choice of an Education Destination - A correspondence Analysis, Journal of Marketing for Higher Education 15(2). 31- 46.

Tamtekin A. O. (2015). University choice process: a literature review on models and factors affecting the process. yuksekogretim Dergisi, doi:10.2399/yod.15.008. Online available at: www.yuksekogretim.org.

Wagner, K. \& Fard, P.Y. (2009). Factors influencing Malaysian student's intention to study higher educational institution. Accessed on: $15^{\text {th }}$ May, 2019: Retrieved from http//library.oum.edu.my/repository/365/1/Wagner.

Yamamoto, G. T. (2006). University evaluation-selection: A Turkish case. International Journal of Educational Management, 20(7), 559-569.

Yusof, M., Ahmad, S. N.B., Tajudin, M. \& Ravindran, R. (2008). A study of factors influencing the selection of a higher education institution. UNITAR e-journal, 4(2), 27-40.

Zhi-Hong, C. (2014). Exploring students' behaviors in a competition-driven educational game. Computers in Human Behavior, (35), 68-74. 